\section{His Majesty King Felipe VI}

\section{Anguita JV*}

President Presa Gibraltar Strait Bridge, Spain

*Corresponding author: Anguita JV, President Presa Gibraltar Strait Bridge, Spain, Tel: +34 607222 035; E-mail: juanvalle1952@hotmail.com

Received date: July 08, 2016, Accepted date: July 30, 2016, Published date: August 2, 2016

Copyright: (c) 2016 Anguita JV. This is an open-access article distributed under the terms of the Creative Commons Attribution License, which permits unrestricted use, distribution, and reproduction in any medium, provided the original author and source are credited.

Citation: Anguita JV (2016) His Majesty King Felipe VI. J Entrepren Organiz Manag 5: 193. doi:10.4172/2169-026X.1000193

\section{Regarding: Project Dam Bridge}

His Majesty King Felipe VI

Casa Real Spanish

Zarzuela Palace

Fax: 915992416

28071 Madrid

Spain

\section{Excellency King of Spain}

By the agreement signed in 1979 [1] by their majesties the kings of Morocco and Spain, have studied two alternatives: Bridge and Tunnel now and although the two are a fixed link, do not solve the current problem (the imminent rise in sea due to global warming). (See video "The land under water").

The Mediterranean for its strategic position is the only sea which can protect against the rising waters of the Atlantic Ocean, the result of melting polar ice, as it says in the video.

In any way, I want to debunk the great work of research that have been conducted for over thirty-five, all still valid and very important for the third alternative, which in previous occasion I sent it to His Majesty Don Juan Carlos I.

We just want this third way, is taken into account for a feasibility study or not. Since our First Dam Project Gibraltar Strait Bridge is also a fixed link, very simple, feasible and more economical.

Dam: it is to further strengthen the Strait of Gibraltar, through add blocks of rock (riprap) on both sides of the sea to leave a gap or light 2 $\mathrm{km}$ vain. For the passage of ships, submarines, marine flora and fauna.

Bridge: On this gap $2 \mathrm{~km}$. a bridge linking the two continents will be built. But for now we do not consider, in this site the locks or gates to regulate the level of the Mediterranean Sea will be installed.

With this project are 24 countries that can benefit at the same time, and so will not have to do it individually; in addition, more than 15,000 islands and thousands of $\mathrm{Km}$. of coastline which can be protected.

This third way, the Project Dam Bridge, is 10 times cheaper than any of the first two alternatives and 20 times less than the dam Piter Jansen (video Underwater Earth) Earth under water.

This project would not cost a penny, to Spain or Morocco, as would be built through the system of concessions, as they are doing in the construction of the Grand Canal of Nicaragua or others.
The sea rise is imminent, many islands in the Caribbean, Oceania or Africa are in danger of disappearing, and they cannot do anything, to ask the developed world to reduce its emissions of greenhouse gases (GHGs). And yet, perhaps because it is too late. But we, the Mediterranean, we have a choice, we should not miss, their support is essential.

We want the Dam Bridge Strait of Gibraltar project is studied by professionals and gladly are happy to give our collaboration in every way. We want to make a $3 \mathrm{D}$ video to show the full extent, the dimensions of the project; we are looking for sponsors.

On the other hand, we want to tell that we have sent to the Vatican our preliminary project and the Pope deigned to grant a hearing on September 16, 2015. Similarly, we are looking for ways to make it reach Ambassador Arctic: Alejandro Sanz [2].

Finally, this Mega project, generate work for more than three hundred thousand people, both directly and indirectly contributing to the growth of Spain (Europe) and allowing the development and democratization of Africa in general.

Finally, I attached the information available.

\section{The Problem:}

Video the land underwater, Earth under water [3]

2. The Solution to the Mediterranean:

Dam Project to Gibraltar Strait Bridge (PPEGSA) [4]

Best regard,

Juan Valle Anguita

Gibraltar Strait Bridge Dam, S.A.

juanvalle1952@hotmail.com

$+34607222035$

Tito Hernandez Pinto [5]

\section{References}

1. http://www.secegsa.gob.es/SECEGSA/LANG_CASTELLANO/ TRANSPARENCIA/INFO_CORP/marco_institucional.htm

2. http://www.greenpeace.org/espana/es/news/2014/Enero/Obama-respondea-la-peticion-de-Alejandro-Sanz-para-que-EEUU-apoye-la-creacion-deun-santuario-en-el-Artico/\#

3. https://youtu.be/La5W3opGQt4

4. http://goo.gl/hffl4A

5. http://proyectoeurafrica.blogspot.com.es 